\title{
Variation in leaf morphology and branching pattern of some tropical rain forest species from Guadeloupe (French West Indies) under semi-controlled light conditions
}

\author{
M Ducrey \\ INRA, Laboratoire de Recherches Forestières Méditerranéennes, \\ Avenue A Vivaldi, F-84000 Avignon, France
}

(Received 18 March 1992; accepted 7 July 1992)

\begin{abstract}
Summary - Seedlings of 7 canopy species from the Guadeloupe tropical rain forest (Dacryodes excelsa, Amanoa caribaea, Richeria grandis, Simaruba amara, Symphonia globulifera, Byrsonima coriacea and Podocarpus coriaceus) were raised in full sunlight and under artifical neutral shade transmitting $6,11,19$ and $54 \%$ light for 2 to 3 years. At the end of this period, the number of leaves and branches, leaf size, specific leaf area and stomatal density were observed for each plant. For all species, the maximum number of leaves was obtained in partial shade (11 or $19 \%$ sunlight). Branching occurrence depended more on species type than on light conditions. Both individual leaf size and specific leaf area increased regularly with shade, but in a proportion which varied according to the species. Stomatal density was highly variable from one species to another and increased with greater light. The morphological plasticity of species response to light conditions was then analysed and related to shade tolerance. In order of decreasing plasticity, the first species found were $R$ grandis, $S$ amara and $B$ coriacea, which were the most plastic and the most shade intolerant, followed by $A$ caribaea and $P$ coriaceus, less plastic but shade-tolerant species. Finally, $D$ excelsa and $S$ globulifera were found to be the least plastic species and highly or moderately shade-tolerant.
\end{abstract}

tropical rain forest / leaf morphology / specific leaf area / branching pattern / shade tolerance

Résumé - Variations de la morphologie foliaire et branchaison de quelques espèces de la forêt tropicale humide de Guadeloupe en conditions semi-contrôlées d'éclairement. De jeunes semis de 7 espèces de la strate arborescente de la forêt tropicale humide de Guadeloupe (Dacryodes excelsa, Amanoa caribaea, Richeria grandis, Simaruba amara, Symphonia globulifera, Byrsonima coriacea et Podocarpus coriaceus) ont été élevés pendant 2-3 ans en pleine lumière et sous ombrages artificiels neutres laissant passer $6 \%, 11 \%, 19 \%$ et $54 \%$ de la pleine lumière. À la fin de cette période on a observé sur chaque plant, le nombre de feuilles et de ramifications, la taille et la surface spécifique des feuilles ainsi que la densité stomatique. Pour toutes les espèces étudiées, le nombre de feuilles est maximal pour des ombrages moyens (11 ou $19 \%$ de la pleine lumière). La présence de ramifications dépend davantage des espèces que des conditions d'éclairement. La surface individuelle des feuilles ainsi que leur surface spécifique augmentent régulièrement avec l'om- 
brage mais dans des proportions variables selon les espèces. La densité stomatique, très variable d'une espèce à l'autre, augmente avec l'éclairement. La plasticité morphologique des espèces en réponse aux conditions d'éclairement est ensuite analysée et interprétée en termes de tolérance à l'ombrage. Par ordre de plasticité décroissante, on trouve $\mathrm{R}$ grandis, $\mathrm{S}$ amara et $\mathrm{B}$ coriacea qui sont les espèces les plus plastiques et les plus intolérantes à l'ombrage. On trouve ensuite A caribaea et $\mathrm{P}$ coriaceus, moins plastiques mais tolérantes à l'ombrage. D excelsa, et $\mathrm{S}$ globulifera sont les moins plastiques et sont modérément ou fortement tolérantes à l'ombrage.

forêt tropicale humide / morphologie foliaire / surface foliaire spécifique / blanchaison / tolérance à l'ombrage

\section{INTRODUCTION}

The reaction of trees to varying light environments, particularly to shade, can be compared at different levels. First of all, at the species level, we find species which require full sunlight and others which are more or less shade-tolerant. On the individual level, within the same species or genotype, we find trees which have grown in different light environments and have different phenotypes (shade phenotypes or sun phenotypes). Finally, within the same individual, particularly within a stand, sun and shade leaves are found, depending on their position in the tree crown.

These facts are generally known for most tree species growing in temperate climates, but have been less studied for tropical species. In particular, the shade response of the main commercial species in the tropical rainforest of Guadeloupe is practically unknown.

The experiments conducted (Ducrey, 1982; Ducrey and Labbé, 1985) on stimulated and controlled natural regeneration in the Guadeloupe rainforest provided the first results (Ducrey and Labbé, 1986) on the forest behaviour of the main tree species favoured for natural regeneration. Methods similar to the progressive felling regeneration and the tropical shelterwood system were adopted. Survival and growth of seedlings from different species were studied under 2 different thinning intensities. The variations in environmental conditions due to the different silvicultural treatments were then used as a means of determining the range of light requirements in the species studied, from the most shade-intolerant to the most shade-tolerant.

A uniquely silvicultural approach is not sufficient to understand the forest behaviour of a given species and its relative place in a forest succession. It therefore seemed of interest to further the knowledge on these species by studying morphological variations in leaves and branching pattern in response to light conditions during growth. This approach is of value for 2 reasons. First of all, the use of morphological criteria to account for physiological potentials under varying light conditions appears to be possible using existing relationships between physiological and morphogenetic processes (Tsel'Niker, 1977). Secondly, the range of morphological variations in the leaf system under extreme light conditions is a good means of determining the forest behaviour of a given species (Smith, 1982; Fetcher et al, 1983; Goulet and Bellefleur, 1986).

This article examines the morphological variations in leaves and branching pattern for 7 evergreen species subjected to 5 different light conditions. The experiment also took into account photosynthetic response, growth and biomass production, which will be discussed in further papers. 


\section{MATERIALS AND METHODS}

\section{Description of seedlings of species studied}

The seedlings used for the experiment were sampled from the tropical rainforest of Guadeloupe, French West Indies. They came from the "Débauchée" area (Ducrey, 1986) at an elevation of $250 \mathrm{~m}$. Mean temperatures were $23^{\circ} \mathrm{C}$ in January and $26^{\circ} \mathrm{C}$ in July. Mean annual rainfall was $>3000 \mathrm{~mm}$. There was a short dry season from January to April, but the monthly rainfall was always $>100 \mathrm{~mm}$.

The 7 species studied were evergreen dominant and co-dominant trees from the middle and late successional gradient of the Guadeloupe rainforest: Dacryodes excelsa Vahl, Amanoa caribaea Kr et Urb and Podocarpus coriaceus LC Rich are late successional shade-tolerant species; Simaruba amara Aubl and Richeria grandis Vahl are middle successional shade-intolerant species; Byrsonima coriacea is present in middle and late succession, whereas Symphonia globulifera L, a wet soil specialist, is a late successional species. However, their shade reaction is not well known.

$D$ excelsa and $S$ amara have compound leaves, while the other species have simple leaves. All could be easily identified in the forest understorey with the exception of $B$ coriacea, which was difficult to differentiate when young from 2 neighbouring forms, the "Patagonian" Byrsonima and the "Coal wood" Byrsonima.

\section{Experimental treatments}

The 1-yr-old seedlings were sampled from the forest margin in January 1981, transplanted in 9-I containers filled with surface forest soil, and placed under the forest canopy to ensure better recovery. After 3 months, the containers were transferred to tunnel shelters covered with shade cloths to obtain the required amount of shade. Seedlings were then between 10 and $20 \mathrm{~cm}$ height.

The seedlings were separated into 5 different treatment groups: 4 treatments under plastic tunnels and one treatment in the open air and full sunlight. The 4 tunnel shelters were $15 \mathrm{~m}$ long and $6 \mathrm{~m}$ wide and covered with reinforced transparent PVC as a protection against rainfall. Three of them were shaded with different black neutral shade screens in order to obtain various shade conditions. Finally, global radiation measurements with $\mathrm{Li}$-Cor pyranometers indicated $6.4 \%$ light under tunnel I, $11.4 \%$ under tunnel II, $18.8 \%$ under tunnel III and $54.3 \%$ under tunnel IV.

Table I summarizes climatic data under tunnel shelters. These were opened and oriented in the direction of prevailing winds. The microclimatic conditions under the tunnels were the same as those in the open air treatment (meteorological data measured by a weather station), except for tunnel IV whose maximum temperatures were slightly higher than the others. This could be explained, as the shade under this tunnel was only created by the reinforced transparent plastic cover which caused a more significant warming effect.

The protocol was applied to all the species except $P$ coriaceus and $A$ caribaea. The $P$ coriaceus seedlings were placed under the same moderately shaded tunnel (tunnel III) in March 1981 and then subjected to the different experimental conditions in January 1982. The experiment with A caribaea started in March 1982.

In each tunnel, plants were grouped by species with a container density of 16 plants per $\mathrm{m}^{2}$. All the plant groups were moved once a week inside each tunnel so that they occupied the same place every 8 weeks. This was undertaken to uniformize growth light conditions. At the beginning of the shading experiment, there were between 30 and 40 plants per species and per treatment. The number of plants remaining at the end of the experiment is given in tables II and III. Containers were watered twice a week. No fertilizer was used during the experiment.

\section{Plant observations and measurements}

At the end of the experiment (between March 1983 and January 1984 depending on the species) when the plants were approximately 1.00 $1.50 \mathrm{~m}$ in height, several observations were made: counting leaves on the main stem and on branches, dry weight and surface area of 2 randomly selected leaves from the stem and 2 leaves from the branches on each plant. The 


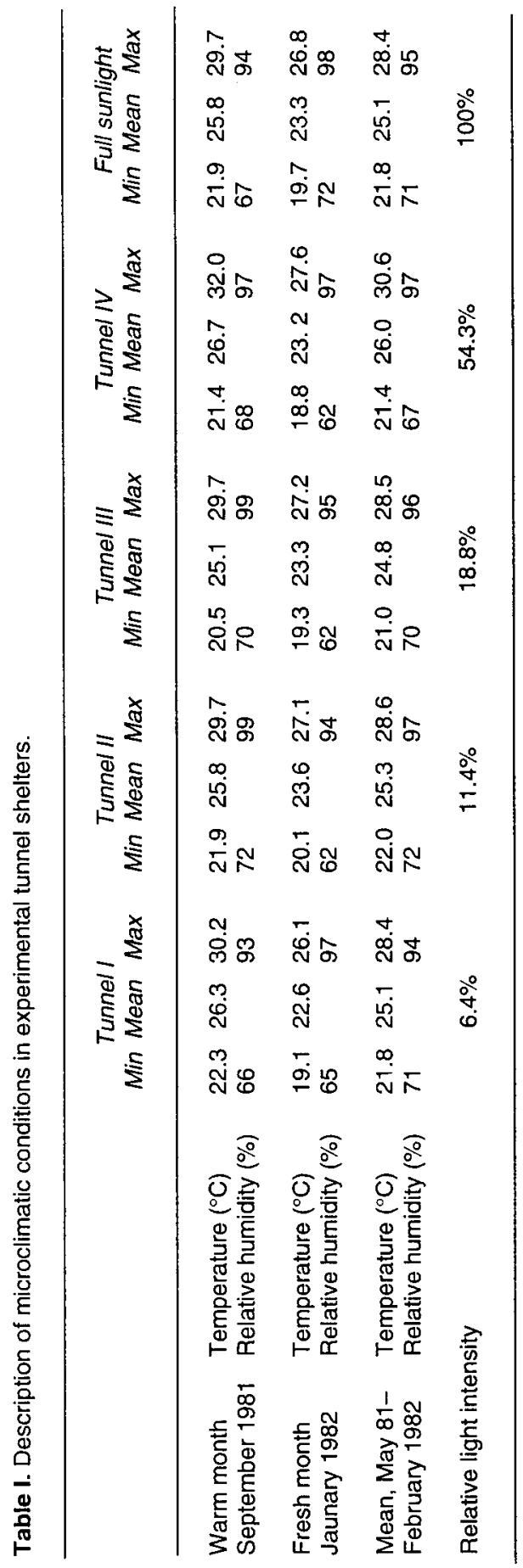


Table II. Number of leaves and branches for simple-leaved species. For each species, identical letters indicate means not significantly different $(P<0.05)$ according to Duncan's multiple range test.

\begin{tabular}{|c|c|c|c|c|c|c|c|}
\hline \multirow[t]{2}{*}{ Species } & \multirow[t]{2}{*}{ Tunnel } & \multirow{2}{*}{$\begin{array}{c}\text { No } \\
\text { of } \\
\text { plants }\end{array}$} & \multicolumn{3}{|c|}{$\begin{array}{c}\text { Mean number of leaves } \\
\text { per plant }\end{array}$} & \multirow{2}{*}{$\begin{array}{l}\text { Branched } \\
\text { plants } \\
\text { (\%) }\end{array}$} & \multirow{2}{*}{$\begin{array}{c}\text { No of } \\
\text { branches per } \\
\text { branched } \\
\text { plant }\end{array}$} \\
\hline & & & $\begin{array}{l}\text { On the } \\
\text { shoot }\end{array}$ & $\begin{array}{c}\text { On the } \\
\text { branches }\end{array}$ & Total & & \\
\hline $\begin{array}{l}\text { Amanoa } \\
\text { caribaea }\end{array}$ & $\begin{array}{l}\text { I } \\
\text { II } \\
\text { III } \\
\text { IV } \\
\text { Full sunlight }\end{array}$ & $\begin{array}{l}33 \\
41 \\
36 \\
38 \\
32\end{array}$ & $\begin{array}{l}19^{b} \\
22^{a} \\
17^{b} \\
17^{b} \\
17^{b}\end{array}$ & $\begin{array}{c}45^{c} \\
78^{b} \\
112^{a} \\
96^{a b} \\
42^{c}\end{array}$ & $\begin{array}{r}64^{b} \\
100^{a} \\
129^{a} \\
113^{a} \\
59^{b}\end{array}$ & $\begin{array}{r}100 \\
100 \\
100 \\
81 \\
87\end{array}$ & $\begin{array}{r}7 \\
11 \\
18 \\
19 \\
8\end{array}$ \\
\hline $\begin{array}{l}\text { Richeria } \\
\text { grandis }\end{array}$ & $\begin{array}{l}\text { I } \\
\text { II } \\
\text { III } \\
\text { IV } \\
\text { Full sunlight }\end{array}$ & $\begin{array}{l}35 \\
32 \\
32 \\
28 \\
27\end{array}$ & $\begin{array}{l}20^{a} \\
24^{b} \\
26^{b} \\
20^{a} \\
21^{a}\end{array}$ & & $\begin{array}{l}20^{a} \\
24^{b} \\
26^{b} \\
20^{a} \\
21^{a}\end{array}$ & $\begin{array}{l}3 \\
6 \\
6 \\
6 \\
0\end{array}$ & $\begin{array}{l}1 \\
2 \\
4 \\
1 \\
-\end{array}$ \\
\hline $\begin{array}{l}\text { Symphonia } \\
\text { globulifera }\end{array}$ & $\begin{array}{l}\text { I } \\
\text { II } \\
\text { III } \\
\text { IV } \\
\text { Full sunlight }\end{array}$ & $\begin{array}{l}37 \\
39 \\
38 \\
36 \\
39\end{array}$ & $\begin{array}{l}31^{b} \\
35^{a} \\
27^{b} \\
20^{c} \\
10^{d}\end{array}$ & $\begin{array}{l}133^{a b} \\
147^{a} \\
126^{b} \\
105^{c} \\
64^{d}\end{array}$ & $\begin{array}{l}164^{\mathrm{ab}} \\
182^{\mathrm{a}} \\
153^{\mathrm{b}} \\
125^{\mathrm{c}} \\
74^{\mathrm{d}}\end{array}$ & $\begin{array}{l}100 \\
100 \\
100 \\
100 \\
100\end{array}$ & $\begin{array}{l}15 \\
17 \\
16 \\
17 \\
17\end{array}$ \\
\hline $\begin{array}{l}\text { Byrsonima } \\
\text { coriacea }\end{array}$ & $\begin{array}{l}\text { I } \\
\text { II } \\
\text { III } \\
\text { IV } \\
\text { Full sunlight }\end{array}$ & $\begin{array}{l}29 \\
30 \\
31 \\
31 \\
30\end{array}$ & $\begin{array}{l}37^{a} \\
40^{a} \\
38^{a} \\
29^{b} \\
19^{c}\end{array}$ & $\begin{array}{l}11^{a} \\
16^{a} \\
28^{b c} \\
19^{a b} \\
35^{c}\end{array}$ & $\begin{array}{l}48 \\
56 \\
66 \\
48 \\
54\end{array}$ & $\begin{array}{r}58 \\
80 \\
93 \\
70 \\
100\end{array}$ & $\begin{array}{l}3 \\
4 \\
4 \\
4 \\
5\end{array}$ \\
\hline $\begin{array}{l}\text { Podocarpus } \\
\text { coriaceus }\end{array}$ & $\begin{array}{l}\text { I } \\
\text { II } \\
\text { III } \\
\text { IV } \\
\text { Full sunlight }\end{array}$ & $\begin{array}{l}35 \\
36 \\
36 \\
35 \\
30\end{array}$ & $\begin{array}{l}203^{a} \\
185^{a b} \\
171^{b} \\
123^{c} \\
102^{d}\end{array}$ & $\begin{array}{l}154^{a} \\
195^{a} \\
187^{a} \\
161^{a} \\
158^{a}\end{array}$ & $\begin{array}{l}358^{a} \\
380^{a} \\
358^{a} \\
284^{b} \\
259^{b}\end{array}$ & $\begin{array}{r}97 \\
97 \\
100 \\
91 \\
83\end{array}$ & $\begin{array}{r}9 \\
11 \\
10 \\
6 \\
6\end{array}$ \\
\hline
\end{tabular}

data were used to calculate the specific leaf area $\left(\mathrm{cm}^{2} \mathrm{~g}^{-1}\right)$ of each species for each light condition.

The leaf stomatal density (number of stomata per leaf area unit) was determined during the last quarter of 1982 via leaf prints. A thin collodion film was spread on the leaf surface to prepare a print of epidermic and stomatal cells that could be observed by optical microscopy. These leaf prints were taken for $2-6$ leaves per species and per tunnel and were made systematically on the lower and upper side of the leaves.

\section{RESULTS}

\section{Leaf counting}

Table II summarizes data concerning the mean number of leaves per seedling for simple-leaved species. The mean number of leaves varied from one species to another: 22 on average for $A$ grandis, 54 for $B$ coriacea, 95 for $A$ caribaea, 140 for 
Table III. Number of leaves and leaflets from compound-leaved species. For each species, identical letters indicate means not significantly different $(P<0.05)$ according to Duncan's multiple range test.

\begin{tabular}{|c|c|c|c|c|c|}
\hline \multirow[t]{2}{*}{ Species } & \multirow[t]{2}{*}{ Tunnel } & \multirow{2}{*}{$\begin{array}{c}\text { No } \\
\text { of } \\
\text { plants }\end{array}$} & \multicolumn{3}{|c|}{ Mean No per plant of: } \\
\hline & & & Leaves & Leaflets & Leaflets per leat \\
\hline Dacryodes & 1 & 17 & $11^{a b}$ & 55 ab & 5 \\
\hline \multirow{4}{*}{ excelsa } & II & 8 & $13^{a}$ & $68 \mathrm{a}$ & 5 \\
\hline & III & 10 & $11 \mathrm{ab}$ & $42^{b c}$ & 4 \\
\hline & IV & 6 & $9^{b}$ & $36^{c}$ & 4 \\
\hline & Full sunlight & 20 & $11 a b$ & $36^{c}$ & 3 \\
\hline Simaruba & I & 21 & $10^{a}$ & 74 a & 7 \\
\hline \multirow[t]{4}{*}{ amara } & II & 21 & $9^{a}$ & $34^{b}$ & 4 \\
\hline & III & 21 & $9^{a}$ & $46^{b}$ & 5 \\
\hline & IV & 21 & 9 a & $40^{b}$ & 5 \\
\hline & Full sunlight & 20 & $5^{b}$ & $12^{c}$ & 2 \\
\hline
\end{tabular}

$S$ globulifera and 317 for $P$ coriaceus. For each species, the maximum number of leaves was observed either in tunnel II or III and some statistical differences might have occurred among tunnels. The distribution of leaves on the main axis or on the branches was related to the percentages of branched seedlings and to the number of branches per branched seedling. $R$ grandis leaves were almost entirely situated on the main axis while those of $A$ caribaea, $B$ coriacea and $P$ coriaceus were mainly located on the branches.

Table III provides the same information for compound-leaved species. $D$ excelsa had an average of 11 leaves per plant, but the number of leaflets per leaf increased with increasing shade from 3 in the open air to 5 in the darkest tunnel. $S$ amara had between $5-10$ leaves. It would appear that the number of leaflets per leaf increased with exposure to shade, but the repeated attacks of phyllophagous caterpillars typical of this species made the results difficult to interpret.

\section{Study of branching pattern}

All the seedlings studied were very young. It was thus interesting to note the appearance of branches and their variations under different light conditions (tables II, III).

The compound-leaved species $D$ excelsa and $S$ amara had no branches. These only appeared under natural forest conditions in larger and older trees.

The simple-leaved species had different degrees of branching. $R$ grandis had only just begun to ramify and had very few branches. All the $S$ globulifera seedlings were highly branched and had between 15 and 17 branches per seedling. The other species also had a high percentage of branched plants, often close to $100 \%$. This percentage was maximum under low light conditions for $A$ caribaea and $P$ coriaceus and under sunlight conditions for $B$ coriacea. However, it appeared that branching occurrence was more species-dependent than light regime-dependent. 


\section{Leaf characteristics}

Figure 1 indicates the variations in area of individual leaves or leaflets (for compound-

Leaf area $\left(\mathrm{cm}^{2}\right)$

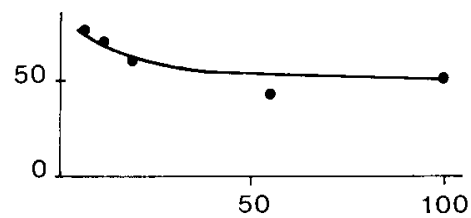

D. EXCELSA
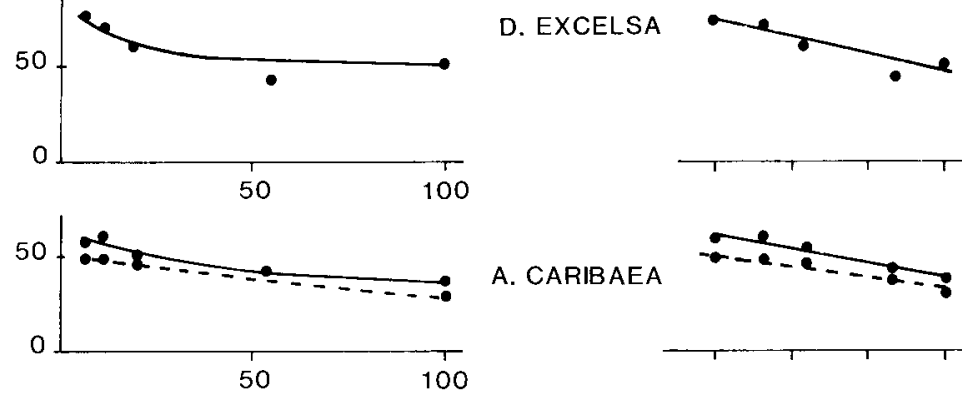

A. CARIBAEA
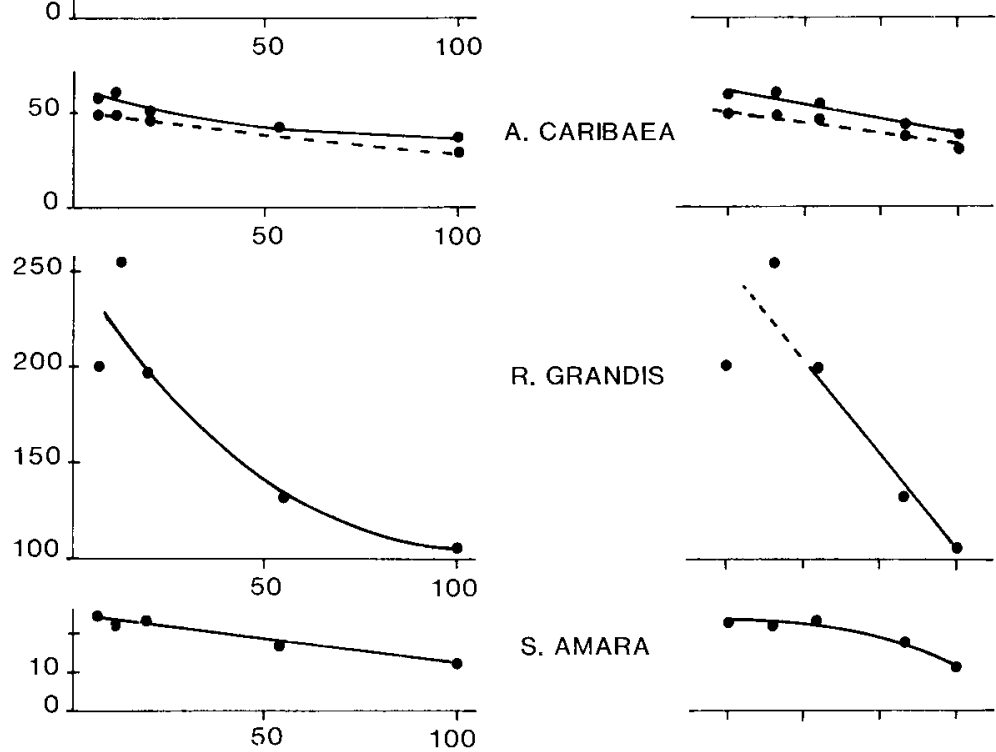

S. AMARA

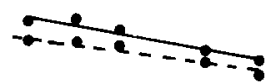

R. GRANDIS
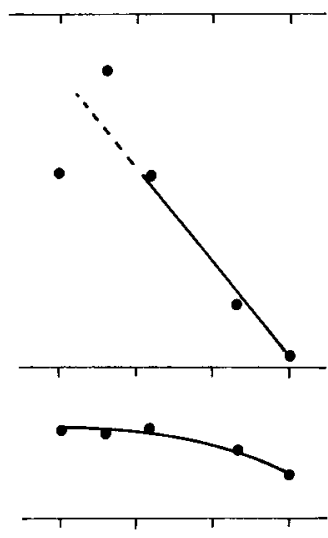

S. GLOBULIFERA
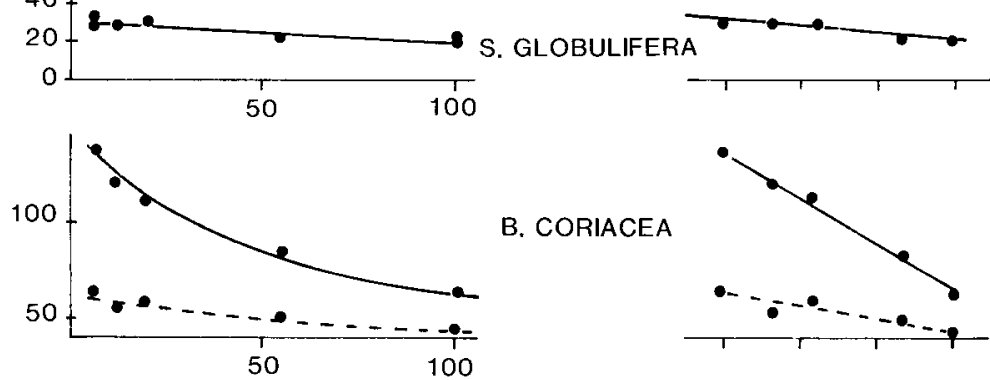

B. CORIACEA
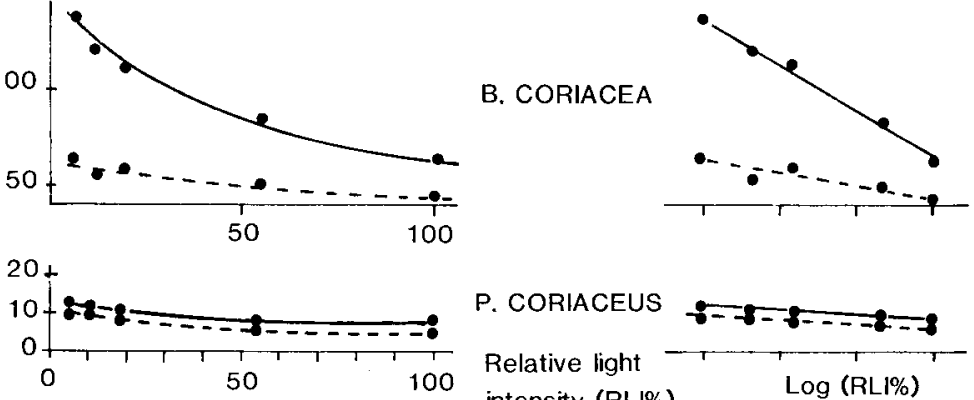

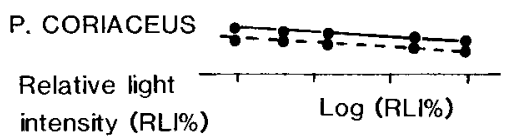

Fig 1. Relationship between individual leaf area (in $\mathrm{cm}^{2}$ ) and light received during growth expressed by relative light intensity (on the left) or by the logarithm of relative light intensity (on the right). General trends are given in full lines for main axis leaves and in dotted lines for branch leaves. 
cies to another. Taking all the tunnels together, the average leaf areas increased from $10 \mathrm{~cm}^{2}$ for $P$ coriaceus to nearly 200 $\mathrm{cm}^{2}$ for $R$ grandis.

There was also a regular decrease in leaf area for all species when relative light increased. Some species reacted strongly to shade and the area of individual leaves more than doubled when going from full sunlight to $6 \%$ sunlight. This was the case for $R$ grandis (150\% increase), $B$ coriacea (120\% increase) and $S$ amara $(100 \%$ increase), followed by $A$ caribaea $(65 \%$ increase), $D$ excelsa, $S$ globulifera and $P$ coriaceus $(50 \%$ increase for each species) which reacted less strongly to variations in light conditions. The right side of figure 1 shows that for most species there was a quasi-linear decrease in individual leaf area in relation to the logarithm of relative light intensity. This demonstrated an exponential variation in relation to relative light intensity, a relationship which has frequently been found for similar phenomena.

Specific leaf area (leaf area recorded by unit of dry leaf biomass) is shown in figure 2. Leaves of all species in full sunlight had a specific area close to $100 \mathrm{~cm}^{2} \mathrm{~g}^{-1}$ except for $P$ coriaceus, whose leaves were thicker and tougher and whose specific leaf area was close to $50 \mathrm{~cm}^{2} \mathrm{~g}^{-1} . S$ amara was the most affected by increasing shade: $149 \%$ increase in specific leaf area when going from full sunlight to shadiest tunnel. It was followed by $R$ grandis, $B$ coriacea and $P$ coriaceus with $\approx 100 \%$ increase, then by $D$ excelsa and $A$ caribaea with $\approx 75 \%$ increase, and finally by $S$ globulifera which had < $50 \%$ increase. As already mentioned for individual leaf area, an exponential decrease in specific leaf area in relation to relative light intensity was found except for $A$ caribaea, $R$ grandis and $S$ amara which were less affected by deep shading.

\section{Stomatal density}

The leaf prints showed that for all the studied species, stomata were present only on the lower side of the leaves. The stomata as well as the epidermic cells had a large variety of forms and sizes, as shown in figure 3. This variability was demonstrated by means comparisons of stomatal density (number of stomata per $\mathrm{mm}^{2}$ ) for each species in each light treatment (table IV).

Stomatal density for full sunlight conditions showed the highest values for $D$ excelsa (661 stomata per $\mathrm{mm}^{2}$ ) and $A$ cari-

Table IV. Stomatal density (No of stomata per $\mathrm{mm}^{2}$ ) on the lower side of leaves for different species from different light conditions. Means \pm SE were calculated from 2-6 leaf prints. For one species, identical letters indicate means not significantly different at the $5 \%$ level according to Duncan's multiple range test.

\begin{tabular}{|c|c|c|c|c|c|}
\hline & Tunnell & Tunnel II & Tunnel III & Tunnel IV & Full sunlight \\
\hline Dacryodes excelsa & $426 \pm 15^{a}$ & $439 \pm 30^{a}$ & $510 \pm 43^{a}$ & $499 \pm 131^{a}$ & $661 \pm 40^{b}$ \\
\hline Amanoa caribaea & $186 \pm 8^{a}$ & $240 \pm 13$ ab & $287 \pm 23^{b}$ & $274 \pm 38 a b$ & $325 \pm 8^{b}$ \\
\hline Richeria grandis & $56 \pm 1$ a & $62 \pm 2 a$ & $82 \pm 12^{a}$ & $100 \pm 23^{a}$ & $172 \pm 23^{b}$ \\
\hline Simaruba amara & $65 \pm 4$ a & $86 \pm 8 a b$ & $96 \pm 8^{b}$ & $124 \pm 7 c$ & $160 \pm 8^{d}$ \\
\hline Symphonia globulifera & $138 \pm 8 a$ & $133 \pm 2$ a & - & - & $139 \pm 8 a$ \\
\hline Byrsonima coriacea & $57 \pm 4^{a}$ & $63 \pm 7 a$ & - & $134 \pm 4^{b}$ & $136 \pm 10^{b}$ \\
\hline Podocarpus coriaceus & $105 \pm 6^{a}$ & $83 \pm 6 a$ & $92 \pm 18$ a & $109 \pm 12^{a}$ & $152 \pm 4 b$ \\
\hline
\end{tabular}


Specific leaf area

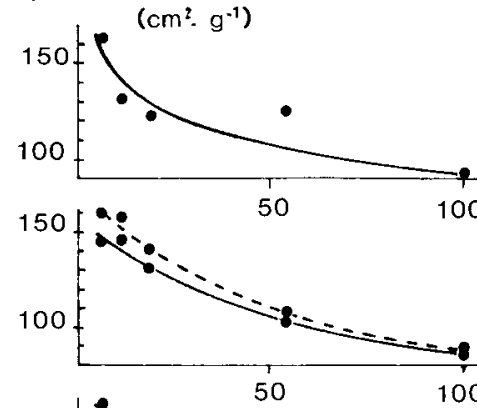

D. EXCELSA

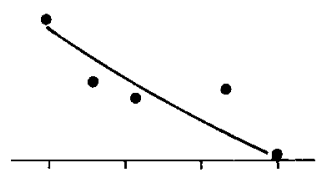

A. CARIBAEA
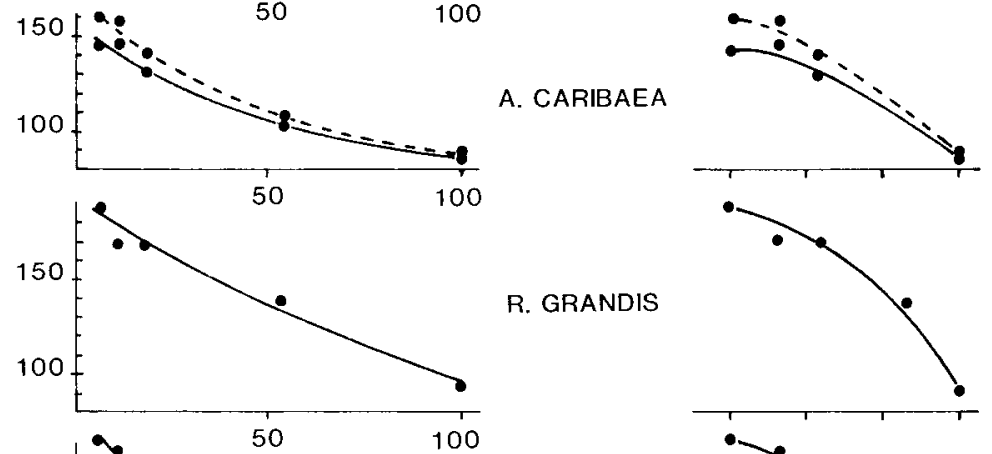

R. GRANDIS
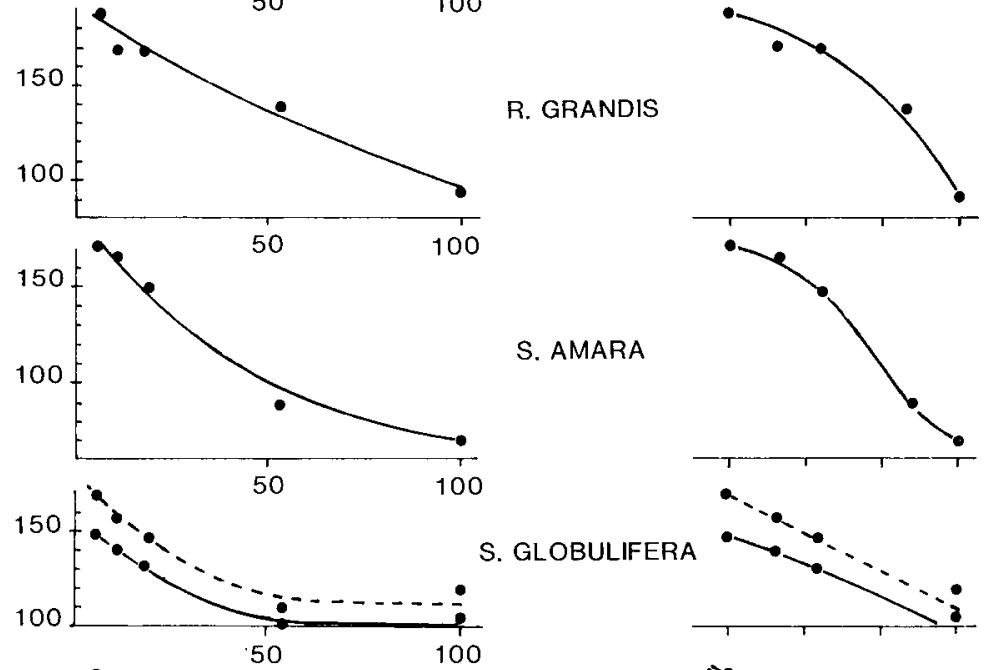

S. GLOBULIFERA
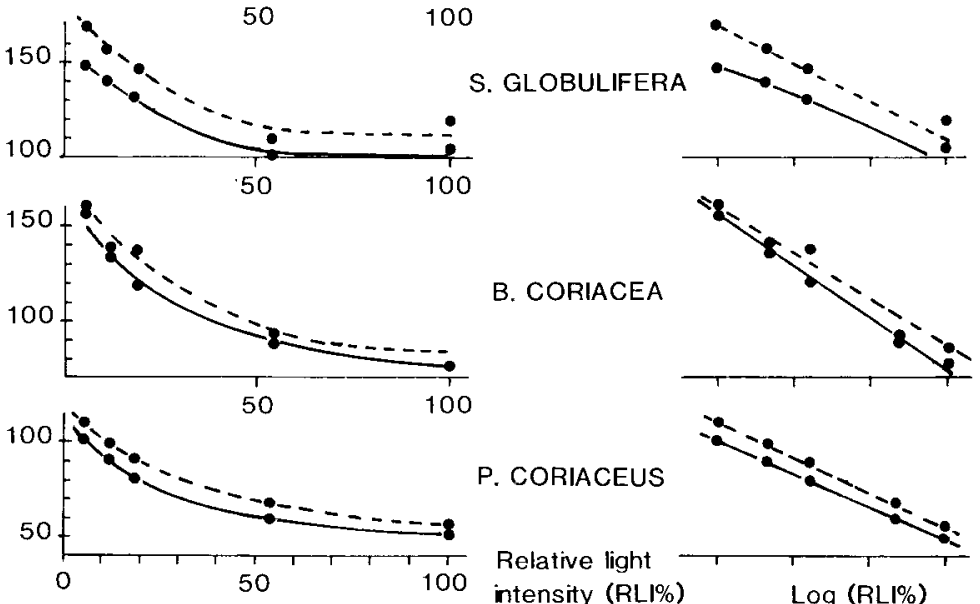

B. CORIACEA

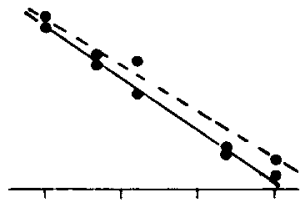

P. CORIACEUS

Relative light intensity $(R L I \%)$

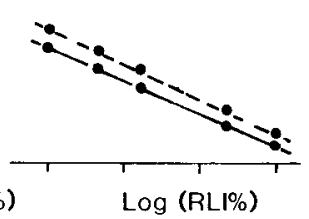

Fig 2. Relationship between specific leaf area (in $\mathrm{cm}^{2} \cdot \mathrm{g}^{-1}$ ) and light received during growth expressed by relative light intensity (on the left) or by the logarithm of relative light intensity (on the right). General trends are given in full lines for main axis leaves and in dotted lines for branch leaves.

baea (325 stomata per $\mathrm{mm}^{2}$ ). The 5 other species had a stomatal density close to 150 stomata per $\mathrm{mm}^{2}$.
Stomatal density was highest under full sunlight conditions and decreased as light intensity diminished. All the species did not 


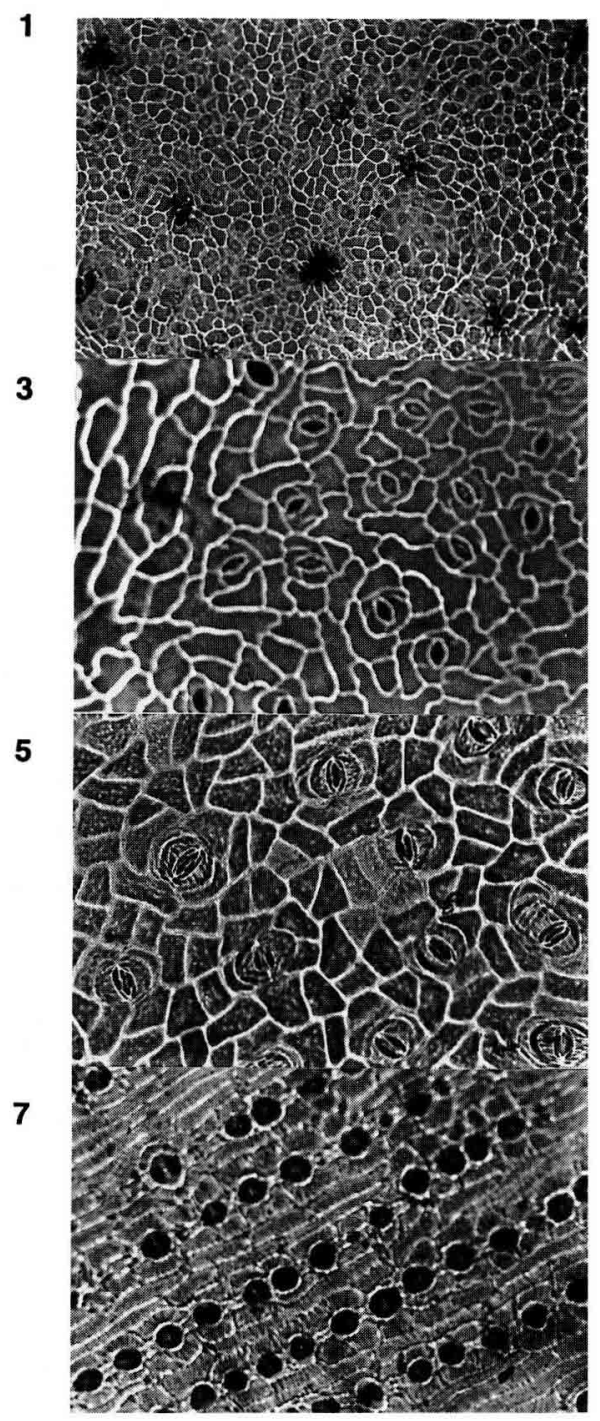

react in the same manner. $R$ grandis was the most affected species with $67 \%$ decreased from full sunlight to the shadiest environment. The decrease in stomatal density was smaller for $S$ amara $(59 \%)$,

\section{2}

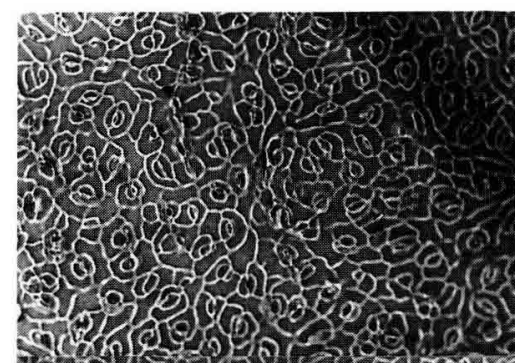

4
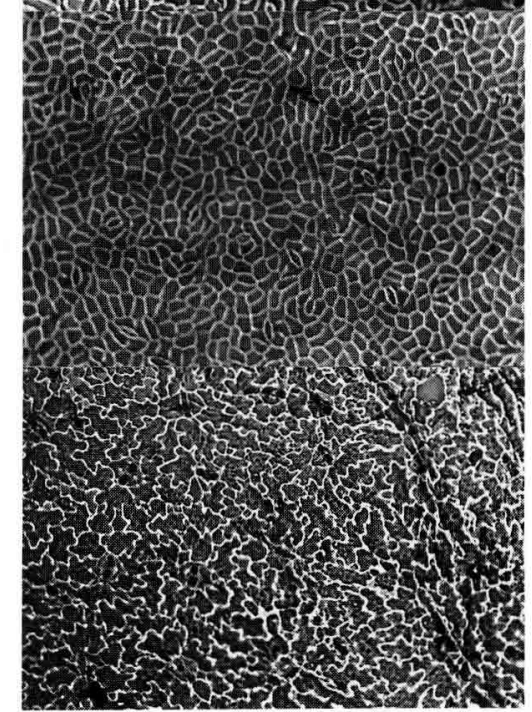

Fig 3. Prints of the lower side of leaves showing the position and shape of stomata and epidermic cells. 1), Dacryodes excelsa; 2), Amanoa caribaea; 3), Richeria grandis, 4), Simaruba amara; 5), Symphonia globulifera; 6), Byrsonima coriacea; 7), Podocarpus coniaceus. Each slide represents $0.4 \mathrm{~mm}^{2}$ of leaf area.

B coriacea (58\%), A caribaea (43\%), P coriaceus $(38 \%)$, and $D$ excelsa $(35 \%)$. In contrast, $S$ globulifera, with only $3 \%$ decrease, did not appear to be affected by shading. 


\section{Morphological plasticity}

Species plasticity for a given trait - leaf size, specific leaf area or stomatal density - may be calculated as the range of this trait from full sunlight to the shadiest condition, divided by corresponding data under full sunlight conditions. For each trait, species plasticity was calculated, and species ranked from the most plastic to the least plastic species (table $\mathrm{V}$ ). Then a mean ranking was calculated which gave an overall appreciation of the morphological plasticity for each species.

Ranked by decreasing order of plasticity, it was found that $R$ grandis, $S$ amara and $B$ coriacea were the most plastic species, $A$ caribaea and $P$ coriaceus the medium-plastic species, and finally $D$ excelsa and $S$ globulifera the least plastic species.

\section{DISCUSSION AND CONCLUSION}

Large differences were observed regarding leaf morphology and branching pattern between the species depending on light conditions. The interpretation of these differences in terms of light behaviour could improve knowledge on the ability of different species to grow under determined light conditions.

\section{Counting of leaves and ramifications}

In general for all the studied species there were more leaves in tunnels II and III than in the others. The decrease under strong light conditions could be due to a more rapid aging which brought about premature leaf fall. The decrease under lower light conditions could be due to a decrease in morphogenetic activity following a nutritional and energetic deficiency.
Some authors (Logan and Krotkov, 1969; Loach, 1970) found that with temperate species the number of leaves reached a maximum in full sunlight. In many deciduous leaved species, the number of leaves is set from budbreak, while in evergreen tropical species growth is more or less continuous and the number of leaves present at a given moment is more highly related to environmental conditions.

According to Smith (1982), the branching ability could be considered as a criterion for adaptation to shade. This hypothesis agrees with that of Bazzaz and Pickett (1980), who found that trees in the first successional stages ramify little and have weak branches. Such a lack of branches was observed from young-aged pioneer species present in Guadeloupe: Cecropia peltata and to a lesser degree Miconia mirabilis.

For the species studied, a lack of branches was also the case for $R$ grandis and $S$ amara which appear in the middle successional stages of species during colonization of open areas by forest. On the other hand, $D$ excelsa, a final species in the succession, was not branched either. There are thus species-specific differences independent of adaptation to shade. The other species were all more or less branched. Except for $B$ coriacea, more seedlings were branched in the shadiest tunnels than in the open air. These results show a tendency towards a greater occupation of available space for better energy capture by plants grown in the shade.

\section{Individual leaf area}

For all the species studied, shade increased leaf size. Some species reacted very strongly: $A$ grandis, $B$ coriacea and $S$ amara; other species reacted less: $P$ coriaceus, $S$ globulifera and $D$ excelsa; 
A caribaea fell between the 2 groups. The results from various reports in the literature, in particular those of Logan and Krotkov (1969), Logan (1970), Loach (1970), McClendon and McMillan (1982) showed that shade does not always have the same effect.

From these authors, it appears that some species, such as Populus deltoides, Populus tremuloides or Prunus americanus react negatively to shade. Others such as Quercus rubra or Acer saccharum barely show any reaction. Still others such as Morus alba, Fraxinus pennsylvanica or $\mathrm{Li}$ riodendron tulipifera react very positively to shade (leaves twice the size). In the latter species, however, too much shade can have a depressive effect. This is what was also observed in $R$ grandis.

\section{Specific leaf area}

Shade has the most noticeable and consistent effect on the specific leaf area. Leaves of equal dry weight always had a larger surface area in shade than in sunlight. The effect of shade, however, differed depending on the species, as illustrated in table $V$ which shows the plasticity of specific leaf area in response to light environment.

$S$ amara was the most plastic species. It was followed in decreasing order of leaf plasticity by $R$ grandis, $B$ coriacea and $P$ coriaceus, then by $D$ excelsa and $A$ caribaea and finally by $S$ globulifera.

This ranking is basically the same as the typical forest ranking for increasing shade adaptation as found previously (Ducrey and Labbé, 1986). Similar results have been reported by Fetcher et al (1983) who found that in very shady conditions, Heliocarpus appendiculatus, a pioneer or large gap species, was twice as plastic as Dipteryx panamensis, a small gap species (see table VI). Among the temperate species, Loach (1967) found results along the same lines: Liriodendron tulipifera, a shade-intolerant species, was more plastic than Fagus grandifolia, a shade-tolerant species. However, Populus tremuloides, a highly intolerant shade species, does not conform to this rule (table VI).

Results obtained for other species (table VI) show the regular increase in specific leaf area as light decreases. It is always hazardous to compare results obtained under different experimental conditions. Nevertheless, looking at results

Table V. Mean morphological plasticity of studied species leaves considered as a combination of individual leaf area (ILA) plasticity, specific leaf area (SLA) plasticity and stomatal density plasticity. For each plasticity trait species are ranked in parenthesis, in decreasing order of plasticity.

\begin{tabular}{llllllllll}
\hline & \multicolumn{1}{c}{$\begin{array}{c}\text { LA } \\
\text { plasticity }\end{array}$} & \multicolumn{1}{c}{$\begin{array}{c}\text { SLA } \\
\text { plasticity }\end{array}$} & $\begin{array}{c}\text { Stomatal } \\
\text { plasticity }\end{array}$ & $\begin{array}{c}\text { Mean } \\
\text { ranking }\end{array}$ \\
\hline Richeria grandis & 1.50 & $(1)$ & 1.01 & $(2)$ & 0.67 & $(1)$ & 4 & $(1)$ \\
Simaruba amara & 1.00 & $(3)$ & 1.49 & $(1)$ & 0.59 & $(2)$ & 6 & $(2)$ \\
Byrsonima coriacea & 1.20 & $(2)$ & 0.94 & $(3)$ & 0.58 & $(3)$ & 8 & $(3)$ \\
Amanoa caribaea & 0.65 & $(4)$ & 0.71 & $(6)$ & 0.43 & $(4)$ & 14 & $(4)$ \\
Podocarpus coriaceus & 0.50 & $(5)$ & 0.92 & $(4)$ & 0.38 & $(5)$ & 14 & $(4)$ \\
Dacryodes excelsa & 0.50 & $(5)$ & 0.76 & $(5)$ & 0.35 & $(6)$ & 16 & $(6)$ \\
Symphonia globulifera & 0.50 & $(5)$ & 0.43 & $(7)$ & 0.03 & $(7)$ & 19 & $(7)$ \\
\hline
\end{tabular}


obtained for conditions ranging from 13$20 \%$ light, it can be seen that shadetolerant species have a specific leaf area close to 1.4-fold greater than those in full sunlight, while shade-intolerant species have values from 1.8-2.0-fold greater.

Increase in specific leaf area in shade is generally accompanied by a decrease in leaf thickness. Leaves exposed to full sunlight could be twice as thick as leaves in the shade, as shown by Tronchet and Grangirard (1956), Aussenac and Ducrey (1977), Duba and Carpenter (1980), Fetcher et al (1983) and Nygren and Kellomaki (1983). These modifications are accompanied by variations in the relative importance of the lacunose parenchyma and the palisade parenchyma of the leaf (Starzecki, 1974) which may cause changes in the diffusion of carbon dioxide within the leaf and thus in photosynthetic processes.

\section{Stomatal density}

Different stomatal densities were observed from one species to another: in general, many small stomata or few large-sized stomata were found. Our results agree with those of Carpenter and Smith (1975) who found a stomatal density for some 50 shade-grown shrub and arborescent species ranging from 65-900 stomata per $\mathrm{mm}^{2}$ and also with those species reviewed by Willmer (1983).

In particular an increase was observed in stomatal density with increase in light conditions. Similar results were obtained by Fetcher et al (1983) for $H$ appendiculatus whose stomatal density more than doubled when exposed to between 2 and $100 \%$ light. This species also has the particular trait of possessing stomata on the upper side of leaves when in full sunlight, which are absent in strong shade. The same increase in stomatal density in rela- tion to light can be found in Platanus occidentalis (Duba and Carpenter, 1980), and Quercus robur (Tronchet and Grandgirard, 1956), as well as in Quercus sessiliflora and Fagus silvatica (Aussenac and Ducrey, 1977).

Studies on non-woody plants (Schoch et al, 1980) showed that the stomatal index, ie the number of stomata related to the total number of epidermic cells, depends on light conditions. The stomatal index increases when light increases during the ontogenic phase of the leaf. Regarding our results this could indicate that shade has a doubly negative effect on stomatal density: a), by increasing cell size; and b), by decreasing the percentage of stomata in relation to epidermic cells. This is obviously important to the physiological functions of the leaf, particularly to their stomatal conductance.

Differences in stomatal plasticity among species occurred, as shown in table $\mathrm{V}$. Variations in stomatal density from sunlight to shade environments were greater for $R$ grandis, $S$ amara and $B$ coriacea (more shade-intolerant species) than for $A$ caribaea, $P$ coriaceus and $D$ excelsa (more shade-tolerant species). $S$ globulifera, another shade-tolerant species, had no stomatal plasticity at all.

\section{Species plasticity and shade adaptation}

The species studied all reacted to shade by increasing individual leaf area and specific leaf area and by decreasing stomatal density.

Variations in specific leaf area, which is generally accompanied by variations in leaf thickness, demonstrate an adaptation to shade by decreasing the distance travelled by photons to carboxylation sites and by decreasing resistance to the diffusion of carbon dioxide in the mesophile. More 


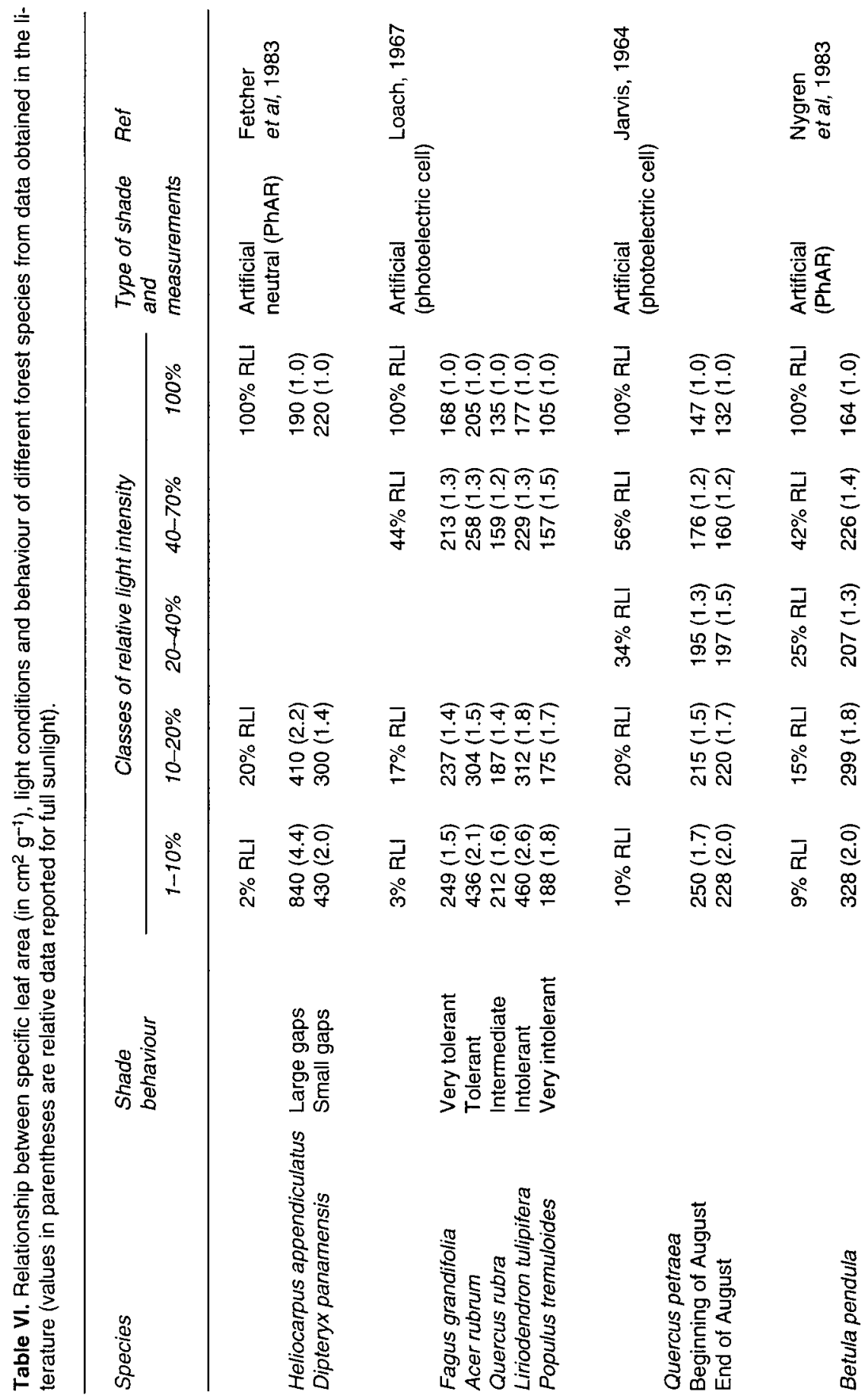


8
8
8
8
0
0
0

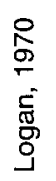

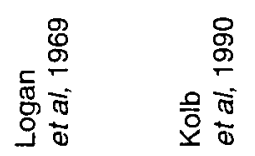

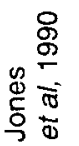

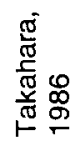

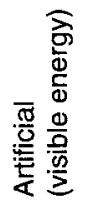

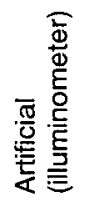

$\frac{\sqrt{00}}{\frac{0}{5}}$

宽

票焉

$\underset{\frac{0}{0}}{\frac{.0}{5}}$

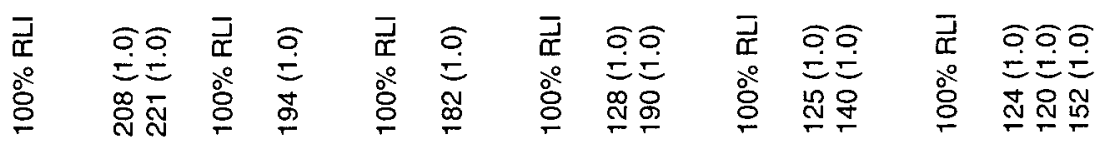

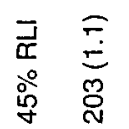

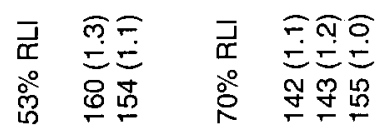

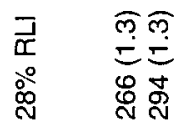

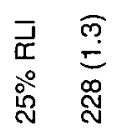

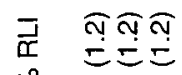

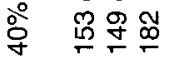

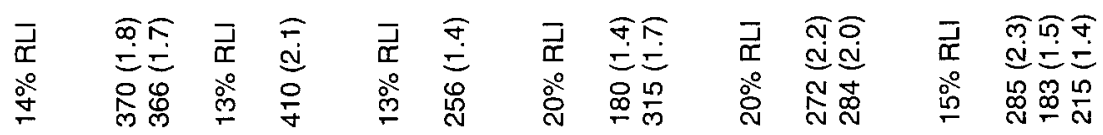
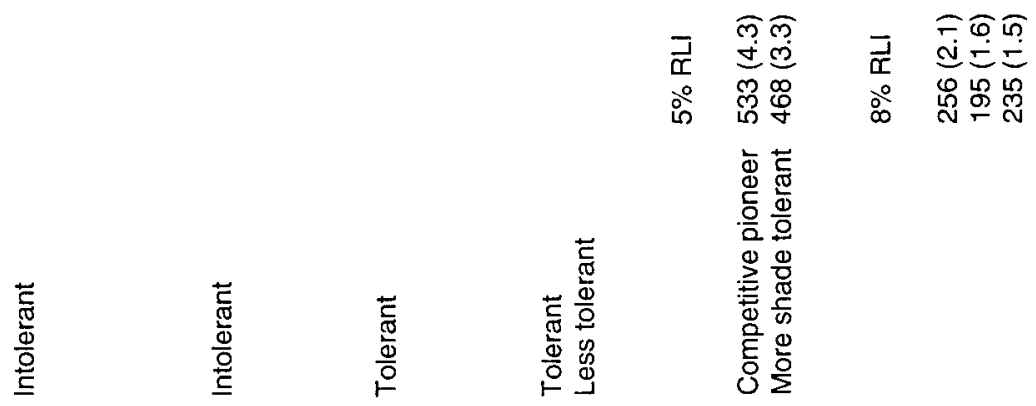

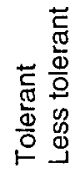

음응

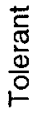

हूํํ일
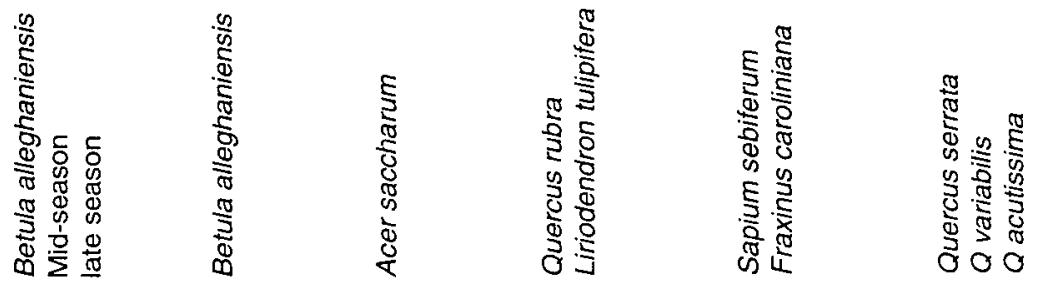

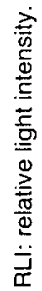


generally, reducing leaf biomass per unit area in shade leaves is a plant strategy used to reduce leaf cost under limiting light environment.

In the same manner, the increase in the amount of stomata in full sunlight shows that the leaf must have a better control of temperature as seen through an increase in stomatal conductance and thus transpiration.

The morphological plasticity of leaves differs from one species to another. Many authors have attempted to link this morphological plasticity to species shade behaviour. For temperate species whose forest behaviour is fairly well known, it is possible to rank species from most to least shade tolerant (Baker, 1949). There is a good agreement between degree of leaf plasticity and shade tolerance where the most plastic species are the most shadeintolerant (see Specific leaf area).

In tropical species, empirical and silvicultural knowledge is basically nonexistent and forest behaviour can only be deduced from morphological variations.

In the species we have studied in Guadeloupe, initial insight into their forest behaviour was obtained through studies on natural regeneration. The results regarding the morphological plasticity of these species are in approximate agreement with the preceding results.

In order of decreasing plasticity, the first species found is $R$ grandis, followed immediately by $S$ amara and then by $B$ coriacea. From growth studies in experimental conditions of natural regeneration (Ducrey and Labbé, 1986), $S$ amara was found to be slightly less shade-tolerant than $R$ grandis. No information was obtained for $B$ coriacea. The following species, in decreasing order of plasticity, are $A$ caribaea which was found to be shade-tolerant and $P$ coriaceus which usually had a reputation of being very shade-tolerant. Finally, the least plastic species are $D$ excelsa which was found to be more shade-tolerant than $A$ caribaea, and $S$ globulifera, another species with a shade-tolerant reputation.

The agreement between these aspects is thus not perfect and morphological criteria alone are insufficient. In fact, many other characters should be examined to investigate tree plasticity in response to light environment. In particular, plasticity should be analysed at a leaf level for photosynthetic light response, biochemistry, anatomy, ultrastructure and morphology, at a plant level and at a canopy level (Boardman, 1977; Bjorkman, 1981; Givnish, 1988).

From a forester's point of view forest behaviour is not a well-defined concept, as shown by the following examples. Shadetolerant versus shade-intolerant behaviour support the assumption that a full sunlight environment is the standard reference. The light-demander species notion implies that some species need more light than others, although most species may grow under full sunlight environments. Other means of explaining differences in tree light response are to consider their place in a forest successional cycle (Bazzaz and Pickett, 1980) from pioneer species to late successional species, or to emphasize growth response to gap size in the forest canopy (Whitmore, 1978; Denslow, 1980, 1987). Other authors (Grime, 1979; Kolb et al, 1990) consider that competition or plant tolerance strategy in response to stresses should include all stress factors and not only light stress.

\section{REFERENCES}

Aussenac G, Ducrey M (1977) Étude bioclimatique d'une futaie feuillue (Fagus silvatica $L$ et Quercus sessiliflora Salisb) de l'Est de la France. I. Analyse des profils microclimatiques et des caractéristiques anatomiques et 
morphologiques de l'appareil foliaire. Ann SCi For 34 (4), 265-284

Baker FS (1949) A revised tolerance table. J For 47, 179-181

Bazzaz FA, Pickett STA (1980) Physiological ecology of tropical succession: a comparative review. Annu Rev Ecol Syst 11, 287-310

Bjorkman O (1981) Response to different quantum flux densities. In: Physiological Plant Ecology. I. Responses to the Physical Environment (Lange $\mathrm{OL}$ et al, eds) Springer Verlag, New York, 57-107

Boardman NK (1977) Comparative photosynthesis of sun and shade plants. Annu Rev Plant Physiol 28, 355-377

Carpenter SB, Smith ND (1975) Stomatal distribution and size in Southern Appalachian hardwoods. Can J Bot 53, 1153-1156

Denslow JS (1980) Gap partitioning among tropical rainforest trees. Biotropica 12 (Tropical succession), 47-55

Denslow JS (1987) Tropical rain forest gaps and tree species diversity. Annu Rev Ecol Syst $18,431-451$

Duba SE, Carpenter SB (1980) Effect of shade on the growth, leaf morphology and photosynthetic capacity of an American sycamore clone. Castanea 45 (4), 219-227

Ducrey $M$ (1982) Study of stimulated natural regeneration in the wet tropical rain forest of Guadeloupe (FWI). In: Forestry in the Caribbean. US MAB rep No 7, 130-133

Ducrey M (1986) Croissance juvénile de quelques espèces introduites dans l'arboretum de Débauchée (Guadeloupe). Rev For Fr 38 (5), 451-456

Ducrey $M$, Labbé $P$ (1985) Étude de la régénération naturelle contrôlée en forêt tropicale humide de Guadeloupe. I. Revue bibliographique, milieu naturel et élaboration d'un protocole expérimental. Ann Sci For 42 (3), 297322

Ducrey $M$, Labbé $P$ (1986) Étude de la régénération naturelle contrôlée en forêt tropicale humide de Guadeloupe. II. Installation et croissance des semis après les coupes d'ensemencement. Ann Sci For 43 (3), 299326

Fetcher N, Strain BR, Oberbauer SF (1983) Effect of light regime on the growth, leaf morphology and water relations of seedlings of two species of tropical trees. Oecologia (Berl) $58,314-319$

Givnish TJ (1988) Adaptation to sun and shade: a whole-plant perspective. Aust J Plant Physiol 15, 63-92

Gordon JC (1969) Effect of shade on photosynthesis and dry weight distribution in yellow birch (Betula alleghaniensis Britton) seedlings. Ecology 50 (5), 924-927

Goulet F, Bellefleur P (1986) Leaf morphology plasticity in response to light environment in deciduous tree species and its implication on forest succession. Can J For Res 16, 11921195

Grime JP (1979) Plant Strategies and Vegetation Processes. John Wiley \& Sons, New York

Jarvis PG (1964) The adaptability to light intensity of seedlings of Quercus petraea (Matt) Liebl. J Ecol 52, 545-571

Jones RH, McLeod KW (1990) Growth and photosynthetic responses to a range of light environments in Chinese tallowtree and Carolina ash seedlings. For Sci 36 (4), 851-862

Ko!b TE, Steiner KC, McCormick LH, Bowersox TW (1990) Growth response of northern redoak and yellow-poplar seedlings to light, soil moisture and nutrients in relation to ecological strategy. For Ecol Manage 38, 65-78

Loach K (1967) Shade tolerance in tree seedlings. I. Leaf photosynthesis and respiration in plants raised under artificial shade. New Phytol 66, 607-621

Loach K (1970) Shade tolerance in tree seedlings. II. Growth analysis of plants raised under artificial shade. New Phytol 69, 273-286

Logan KT (1970) Adaptation of the photosynthetic apparatus of sun- and shade-grown yellow birch (Betula alleghaniensis Britt). Can J Bot 48 (9), 1681-1688

Logan KT, Krotkov G (1969) Adaptation of the photosynthetic mechanism of sugar maple (Acer saccharum) seedlings grown in various light intensities. Physiol Plant 22, 104-116

McClendon JH, McMillan GG (1982) The control of leaf morphology and the tolerance of shade by woody plants. Bot Gaz 143 (1), 79-83

Nygren M, Kellomaki S (1983) Effect of shading on leaf structure and photosynthesis in young birches, Betula pendula Roth and $B$ pubescens Ehrh. For Ecol Manage 7, 119-132 
Schoch PG, Zinsou C, Sibi M (1980) Dependence of the stomatal index on environmental factors during stomatal differentiation in leaves of Vigna sinensis L. I. Effect of light intensity. $J$ Exp Bot 31, 1211-1216

Smith H (1982) Light quality, photoperception and plant strategy. Annu Rev Plant Physiol 33, 481-518

Starzecki W (1974) Topography of photosynthesis in the crowns of Tilia cordata and Acer pseudoplatanus trees. Bull Acad Pol Sci Ser Sci Biol 22 (9), 597-602

Takahara H (1986) Effects of shading on the growth of some Quercus seedlings. J Jpn For Soc 68 (7), 289-292
Tronchet A, Grandgirard A (1956) L'analyse histométrique et son application à l'écologie forestière. Ann Sci Univ Besançon $2^{e}$ Sér Bot $8,3-30$

Tsel'Niker YL (1977) Regulation of processes of $\mathrm{CO}_{2}$ exchange and morphogenesis in seedlings of forest trees under conditions of shading. Sov Plant Physiol 24, 43-48

Whitmore TC (1978) Gaps in the forest canopy. In: Tropical Trees as Living System (Tomlinson PB, Zimmermann MH, eds) Cambridge University Press, 639-655

Willmer CM (1983) Stomata. Longman Inc, New York, $166 \mathrm{pp}$ 